\title{
Millennial tourists and revisit intention
}

\section{Eny Endah Pujiastutia ${ }^{a}$, Hastho Joko Nur Utomo a and Rizka Hermi Novamayantia}

\begin{tabular}{|c|c|}
\hline CHRON I C L E & A B S T RACT \\
\hline $\begin{array}{l}\text { Article history: } \\
\text { Received: February 10, } 2020 \\
\text { Received in revised format: } \\
\text { March } 202020 \\
\text { Accepted: April 17, } 2020 \\
\text { Available online: } \\
\text { April 17, 2020 } \\
\text { Keywords: } \\
\text { Millennials } \\
\text { Revisit intention } \\
\text { Destination trust } \\
\text { Destination image } \\
\text { eWOM }\end{array}$ & $\begin{array}{l}\text { The purpose of this study was to examine the effect of electronic word of mouth and destination } \\
\text { image on revisit intention through the mediating variable of destination trust. Questionnaires were } \\
\text { distributed to } 120 \text { millennial tourists who had visited Gembira Loka Zoo in Yogyakarta for the first } \\
\text { time. The analysis used structural equation modeling and showed that electronic word of mouth } \\
\text { and destination image had both direct and indirect effects on the revisit intention of the tourists. }\end{array}$ \\
\hline
\end{tabular}

\section{Introduction}

Millennial tourists are new to the tourism market (Pendergast, 2010). Millennials have the highest purchasing power and activity rates on social media and are in an age group where connecting to other people is very important. One of the activities carried out by millennial tourists before making a purchase is seeking information, for example, by browsing for reviews from other travelers on Facebook, websites, or Instagram. Bennett (2014) reported that $74 \%$ of travelers make purchasing decisions based on social media. Therefore, examining the behavior of millennial tourists is very important for travel destinations. Millennial tourists were chosen for this study because a growing number of millennials who use social media are influenced by it when making purchasing decisions. The growth in the use of social media affects the behavior of millennial tourists. Social media enables anyone with an internet connection to communicate with everyone else. Social media covers seven broad categories: forums and message boards, review and opinion sites, social networks, blogging, microblogging, bookmarking, and media sharing (Sterve, 2010). A person's online identity comprises daily posts, shared photos, profile updates, and post comments. For millennials, a social media account is a prerequisite for maintaining personal relationships and being socially active (Tsay-Vogel, 2016). As millennials are the digital natives (Prensky, 2012), internet-based booking platforms became a necessity for the survival of tourism businesses. Millennial tourists are a different generation of tourists that need to be studied to identify marketing strategies that meet their needs. This study was carried out in a zoo because it was not only a recreational park for children but also a place of research, education, and conservation. The world was changing, and there was evidence of positive public education about conservation. Thus, there is a need to investigate the target markets for tourism, such as millennial tourists, and the process of their decision-making and post-purchase decision to revisit the zoo. This information is important because millennial tourists have different aspirations in their daily posts, group photos, profile updates, comments and reviews regarding the places that they have visited. Travel destinations must be able to identify with millennials and their lifestyles, and any marketing strategy must be compatible with their needs and aspirations. One way to do this is by paying 
attention to changes in consumer behavior. Managers need to identify attractive activities that will attract millennial tourists so that they will visit or revisit the travel destination. Consequently, managers should be interested in the factors that affect the intention of tourists to revisit because the cost of maintaining previous visitors is lower than the cost of attracting new visitors (Um et al., 2006). Holiday activities or marketing strategies should lead to millennial tourists revisiting, so understanding why tourists revisit is important since these intentions are strong predictors of future behavior (Ajzen, 1991).

Visitors' trust is one of the most important constructs for predicting future intentions to revisit a tourist destination (Morgan $\&$ Hunt, 1994) and the basis for a successful relationship (Moorman et al., 1993). Tourists will revisit a destination because of the image of the destination, and a strong image can increase tourists' trust in the destination. In recent years, the way customers search for information on products and services has changed from using traditional sources to electronic word of mouth (eWOM). eWOM, such as social networking and review posts, has become one of the most influential means of transmitting information (Gruen, Osmonbekov, and Czaplewski, 2006). Reviews have caught on among travelers and tourists as it is possible to review and share experiences, comments, and photographs of their travel (Papathanassis \& Knolle, 2011). Many social media platforms provide tourism information including Facebook, MySpace, Booking.com, and Tripadvisor.com. There are also many travel blogs that can influence decision-making when choosing a travel destination (Wilson et al., 2012; Xiang \& Gretzel, 2010).

eWOM is one of the most frequently sought sources of information for people interested in traveling (Yoon \& Uysal, 2005). Compete (2007) found a third of travelers visited message boards, forums, or online communities before making online purchases because they believed online reviews helped them to make purchasing decisions. Gretzel and Yoo (2008) also pointed out that readers often saw reviews given by other travelers as more up-to-date, pleasant, and reliable information than the information available from travel service providers. Forrester Research (2006) estimated that $34.7 \%$ of online spending is related to travel, and a recent survey indicated that more than $74 \%$ of travelers use the comments of other consumers as reliable information when planning trips for pleasure (Gretzel \& Yoo, 2008). Thus, it is essential to study eWOM because it can have a more powerful effect on consumer behavior and intentions than traditional WOM (Jeong \& Jang, 2011). Previous research into the influence of destination image on destination trust conducted by Chen and Phou (2013), Pujiastuti et al. (2017a), Aprilia et al. (2019), Yerizal and Abror (2019), and Hsu and Liping (2009) concluded that destination image affected destination trust. The similarity in the findings of these studies led us to investigate the effect of destination image on destination trust. Recent studies of the effect of eWOM on destination trust found that the destination image also influenced destination trust (Aprilia et al., 2019; Yerizal \& Abror, 2019). The findings of these studies were similar, leading us to explore the effect of destination image on trust. A study on the effect of eWOM and destination trust on revisit intention was recently conducted by Abu Bakr and Ilkan (2016). Pujiastuti et al. (2017a, 2017b) found that destination trust affected behavior intention (one of the indicators used for revisit intention). Similarly, Destiana et al. (2019) also found that destination image influenced post behavior intention (one of the indicators used for revisit intention). The consistency of the results of these studies led us to investigate the effect of eWOM and trust on revisit intention. Abu Bakar and Ilkan (2016) also found that destination trust influenced revisit intention, and Pujiastuti et al. (2017a, 2017b) concluded that destination trust influenced behavior intention (one of the indicators used for revisit intention). The similarity of these results led us to investigate the relationship between eWOM and destination trust. There have been several studies of the influence of destination image on revisit intention (Prayogo \& Kusumawardhani, 2016; Chen \& Tsai, 2007; Chi \& Qu, 2008; Choi, Tkachenko, and Sil, 2011; Assaker and Hallak, 2013). Destiana et al. (2019) also showed that destination image influenced post behavior intention (one of the indicators used for revisit intention). The similarity in the findings of these studies led us to investigate the influence of eWOM on destination trust. Based on this gap analysis, we identified a lack of information on the effect of eWOM on destination trust and revisit intention in the field of tourism. Although previous studies were consistent, a thorough understanding of trust and the factors that determine the trust tourists place in a travel destination is still lacking. Consequently, we decided to investigate the effects of the destination image and eWOM on destination trust and revisit intention.

This study makes several theoretical contributions to the understanding of tourism. First, this study developed a unified theoretical framework for the importance of destination image and eWOM in the process of choosing a destination. Since many destination images are built from positive online reviews, this leads to the belief that it will reduce the risk of dissatisfaction. Second, the purpose of this study was to analyze the relationship between destination image, eWOM, destination trust, and revisit intention by using the theories of trust and motivation for the first time. Third, this research broadens the existing understanding of the decision-making process of tourists who revisit a destination, how destination image and eWOM affect both destination trust, and the desire to visit again based on a narrow conceptual lens. These relationships have not been examined intensively or directly for tourism.

\section{Literature review}

\subsection{Destination image}

Baloglu and McCleary (1999) defined a destination image as the expression of all knowledge, impressions, prejudices, and emotional thoughts that an individual or group has of a particular object or place. According to Echtner and Ritchie (1991), the destination image is frequently described as simply the "impressions of a place" or the "perceptions of an area." 


\section{$2.2 \mathrm{eWOM}$}

The advent of the internet has extended the idea of word of mouth to an online context known as the electronic word of mouth (eWOM), which can reach large audiences within a short time (Abubakar \& Ilkan, 2013). Kietzmann and Canhoto (2013) defined eWOM as any statement that is based on positive, neutral, or negative experiences made by potential, actual, or experience of a product, service, brand, or company, and which is made available to a multitude of people and institutions via the internet (for example, through websites, social networks, instant messages, and news feeds). eWOM communication is any positive or negative statements made by consumers about products or services that are posted on the internet for individuals and institutions to read (Hennig-Thurau et al., 2004). Dellarocas (2003) indicated that online WOM could have important implications for managers in terms of brand building, product development, and quality assurance.

\subsection{Destination Trust}

Trust can be defined as the certainty that one party has in an exchange partner's reliability and integrity (Sirdeshmukh, Singh, $\&$ Sabol, 2002). Trust towards a tourist destination can be defined as a multidimensional construct, which includes the local inhabitants, and public and private institutions that are honest, benevolent, and competent (Marinao, Torres, and Chasco, 2012). According to Abubakar and Ilkan (2016), destination trust is a visitor's willingness to rely on the ability of a med-tour destination to perform its advertised functions. Destination trust has also been seen as the reliability of important elements pertaining to a location. These elements have been defined as honesty, benevolence, and the competence of local inhabitants (Vogt \& Fesenmaier, 1995; Pizam, 1999), public institutions (Saxena, 2003), and private institutions (Kim et al., 2009; Vásquez, Suárez and Bíaz, 2005). Peter and Oslon (2013) proposed that prominent trust in an object will have an association with the product.

\subsection{Revisit Intention}

The intention to revisit is an eagerness to visit the same place, facility, or location more than once (Cole and Scott, 2004).

\section{Research Model}

The managers of a destination are interested in finding out why millennial tourists want to go back to visit a place, based on the variables of destination image, eWOM, and trust. This study was developed from the research of Pujiastuti et al. (2017), Aprilia et al. (2019), Abubakar et al. (2017), and Prayogo and Kusumawardhani, (2016). The research model developed in our study is shown in Fig. 1.

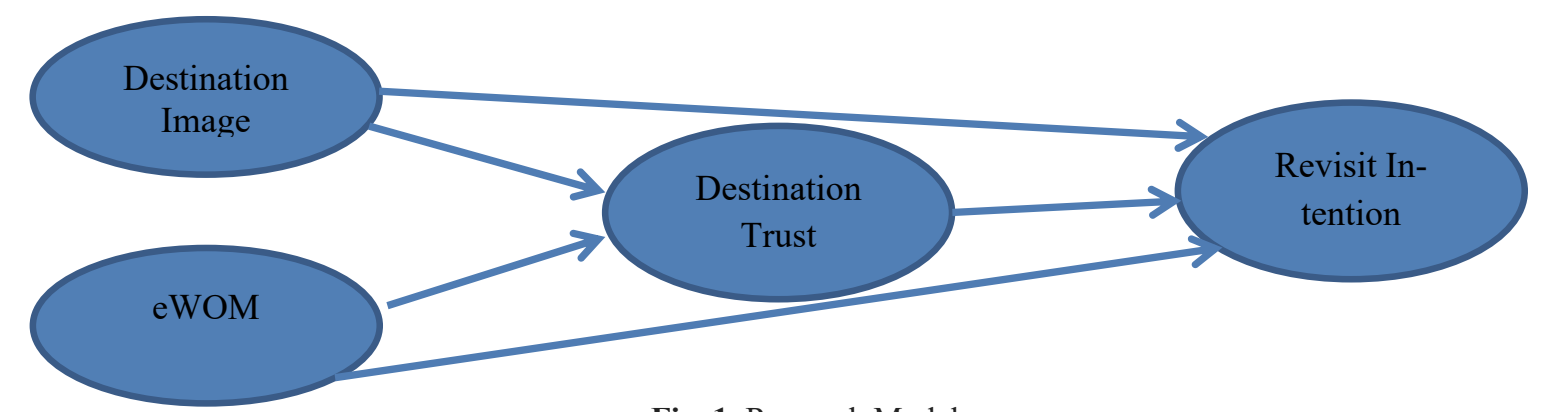

Fig. 1. Research Model

\subsection{Hypotheses}

Pujiastuti et al. (2017), Aprilia et al. (2019), Yerizal and Abror (2019), Hsu and Liping (2009), and Chen and Phou (2013) proposed that destination image had a significant effect on destination trust. Therefore, the first hypothesis of this study was $\mathrm{H}_{1}$ : Destination image has a significant effect on destination trust. Abubakar et al. (2017), Aprilia et al. (2019), and Yerizal and Abror (2019) found that eWOM had a significant effect on destination trust. Therefore, our second hypothesis was $\mathrm{H}_{2}$ : eWOM has a significant effect on destination trust. Prayogo and Kusumawardhani (2016) found that the destination image affected the revisit intention. The results of the study from Chen and Tsai (2007), Chi and Qu (2008), Choi, Tkachenko, and Sil (2011), and Assaker and Hallak (2013) also concluded that destination image influenced the destination selection process and the intention of tourists to revisit. Court and Lupton (1997) found that a positive image of a destination positively affected the intention of tourists to revisit the place. Destination image plays two important roles in behavior: (1) influencing the decision-making process when choosing a destination and (2) conditioning behavior after making a decision, including participation (on-site experience), evaluation (satisfaction) and future behavioral intentions (for example, intention to revisit and willingness to recommend the destination to others) (Ashworth \& Goodall, 1988; Bigne et al., 2001; Cooper, Fletcher, Gilbert, and Wanhill, 1993; Lee et al., 2005; Mansfeld, 1992). After considering these previous studies, we proposed hypothesis H3: Destination image has a significant effect on revisit intention. The results of research conducted by Prayogo and 
Kusumawardhani (2016) showed that eWom influenced revisit intention. Abu bakar and Ilkan (2016) reported that eWOM and trust in tourist destinations affected the desire of tourists to revisit. Therefore, we proposed hypothesis $\mathrm{H}_{4}$ : eWOM has a significant effect on revisit intention. A study by Prayogo and Kusumawardhani (2016) pointed out that eWOM influenced the revisit intention. On the other hand, Abu Bakar and Ilkan (2016) stated that eWOM and trust in tourist destinations affected the desire of tourists to revisit. Therefore, we proposed hypothesis H5: Trust has a significant effect on revisit intention.

The item scale used to assess the destination image, eWOM, destination trust, and revisit intention was adapted and validated from the previous studies. The respondents were asked to share the extent of their search for information, their consideration during the decision-making process, and their enjoyment of the destination by filling in a questionnaire. The questionnaire was divided into two parts. The first part of the questionnaire covered demographic information such as gender, age, and education. The second part contained 28 items for measuring the variables destination image, eWOM, destination trust, and revisit intention. Each construct was assessed on a five-point Likert scale, ranging from 1 (strongly disagree) to 5 (strongly agree). The items in the questionnaire were ordered randomly. Destination image was measured using instruments developed by Chen and Phou (2013) and Munhurrun et al. (2014) and consisted of six items. eWOM was measured using an instrument developed by Prayogo et al. (2016), Abubakar et al. (2016), and Goyette et al. (2010) and consisted of eight items. Destination trust was measured using an instrument developed by Pujiastuti et al. (2017), which included six items. Revisit intention was measured by five items from an instrument developed by Pratmaningsih et al. (2014) and Abubakar et al. (2016). The data used in this study were collected from tourists who visited Gembira Loka Zoo in Yogyakarta in October 2019. Questions were distributed to 120 millennial tourists who had recently visited the zoo. All respondents were recruited voluntarily. The respondents were asked to evaluate the items in the questionnaire. A total of 120 respondents completed the questionnaire, and all 120 responses were used (100\% response rate). SPSS 15 and AMOS 7 software packages were used for Exploratory Factor Analysis (EFA), Confirmatory Factor Analysis (CFA), and Structural Equation Modelling (SEM).

\section{Findings}

In this survey, 120 people participated and two third of them were female. Other personal characteristics of the respondents are shown in Fig. 2.
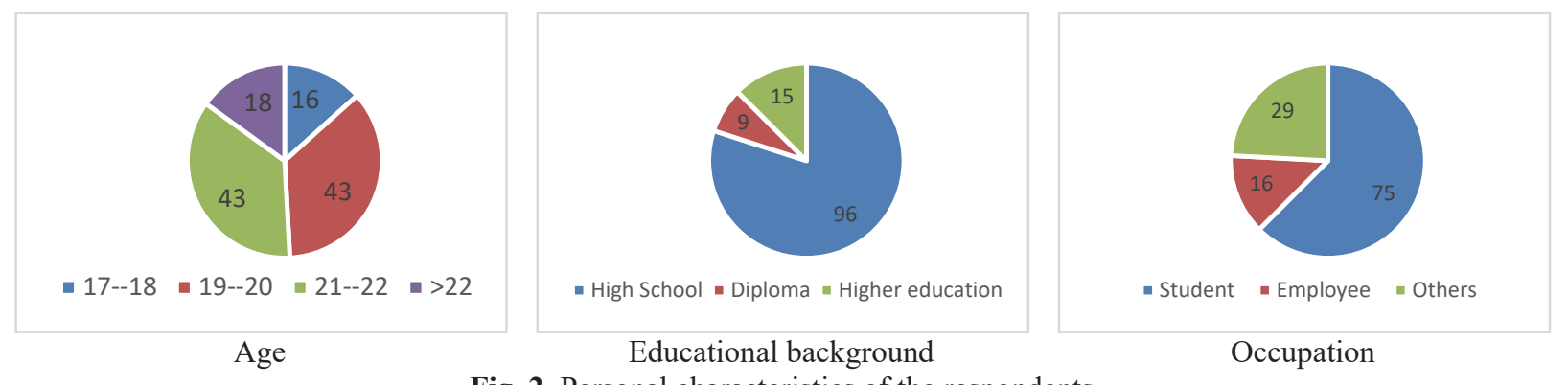

Fig. 2. Personal characteristics of the respondents

\subsection{Confirmatory Factor Analysis and Structural Equation Modelling}

We used CFA to test for convergent validity (Kumar et al., 1998) and found that each item that measured the latent variables had a statistically significant effect (loading factor $>0.7$ and $p$-value $<0.05$ ). The loading factor for each item of the destination image was between 0.796 and 0.874 ; for eWOM, it was between 0.825 and 0.893 ; for destination image, it was between 0.756 and 0.900; and for revisit intention, it was between 0.864 and 0.799. In this study, CFA employed SEM and the AMOS 15 software package to determine the level of compatibility of each item with its latent variable.

Table 1

Cronbach's Alpha for Internal Consistency

\begin{tabular}{lccccc}
\hline Variable & Item & Cronbach's Alpha & Variable & Item & Cronbach's Alpha \\
\hline Destination Image & 6 & 0.9207 & Destination Trust & 6 & 0.9368 \\
eWOM & 8 & 0.9440 & Revisit Intention & 5 & 0.9285 \\
\hline
\end{tabular}

Cronbach's alpha was used to assess the reliability of each group of items from the latent variable. A Cronbach's alpha $>0.70$ indicated a strong internal consistency (Nunnally, 1978). Table 1 shows the Cronbach's alpha for each variable was in the range of 0.921 to 0.929 and confirmed that there was strong internal consistency. The estimation results from the SEM are summarized in Table 3 . These results showed that the model was a good fit $\left(\mathrm{X}^{2}=1.132, \mathrm{CFI}=0.986, \mathrm{GFI}=0.848, \mathrm{TLI}=\right.$ $0.984, \mathrm{NFI}=0.816$, RMSEA $=0.033$ ). This study used revisit intention and destination trust as the dependent variables and destination image and eWOM as the independent variables. 
Table 2

Results from the SEM

\begin{tabular}{|c|c|c|c|c|c|c|c|}
\hline \multicolumn{3}{|c|}{ Effect between Variables } & Estimate & S.E. & C.R. & $\mathrm{P}$ & Hypothesis \\
\hline Destination Image & $\rightarrow$ & Destination Trust & 0.359 & 0.079 & 4.556 & 0.000 & Accepted \\
\hline Electronic Word of Mouth & $\rightarrow$ & Destination Trust & 0.465 & 0.085 & 5.489 & 0.000 & Accepted \\
\hline Destination Image & $\rightarrow$ & Revisit Intention & 0.176 & 0.081 & 2.177 & 0.029 & Accepted \\
\hline Electronic Word of Mouth & $\rightarrow$ & Revisit Intention & 0.178 & 0.087 & 2.037 & 0.042 & Accepted \\
\hline Destination Trust & $\rightarrow$ & Revisit Intention & 0.724 & 0.129 & 5.612 & 0.000 & Accepted \\
\hline
\end{tabular}

We found that the destination image had a positive and significant effect on destination trust $(\beta=0.359, \mathrm{p}=0.000<0.05)$, so hypothesis $\mathrm{H}_{1}$ was accepted. Similarly, eWOM also had a positive and significant effect on destination trust $(\beta=0.465, \mathrm{p}=$ $0.000<0.05)$, so hypothesis $\mathrm{H}_{2}$ was accepted. eWOM had a stronger influence on destination trust than did destination image. Destination image had a positive and significant effect on revisit intention $(\beta=0.176, \mathrm{p}=0.029<0.05)$, so hypothesis $\mathrm{H}_{3}$ was accepted. eWOM also had a positive and significant effect on revisit intention $(\beta=0.178, \mathrm{p}=0.042<0.05)$, so hypothesis $\mathrm{H}_{4}$ was accepted. Similarly, destination trust had a significant influence on revisit intention $(\beta=0.724, \mathrm{p}=0.000<0.05)$, so hypothesis $\mathrm{H}_{5}$ was accepted. The indirect effects of these variables were that the influence of eWOM and destination image on revisit intention would be greater if they also increased destination trust.

\section{Discussion}

\subsection{The destination image had a significant effect on destination trust}

The respondents in this research were millennial tourists who were visiting the destination for the first time, so their trust in the destination involved the destination image. This study revealed that the destination image had a significant and positive influence on destination trust. This finding implied that if the destination image were positive, tourists would be more likely to trust the destination. Conversely, if the destination image were negative, tourists would be more likely to mistrust the destination. The results of this study strengthen the findings of Pujiastuti et al. (2017), Aprilia et al. (2019), Yerizal and Abror (2019), Hsu and Liping (2009), and Chen and Phou (2013), who also found that destination image influenced destination trust. After visiting a destination, tourists compare their expectations with the reality of the visit. If the expectations were in accordance with the reality of the destination, the image of the destination became stronger and vice versa. A strong image for a destination leads tourists to trust the destination, with the result that the branding becomes stronger. For example, the millennial tourist expects that an animal farm will be safe. If the animal farm is safe when they visit it, this reinforces the cognitive perception of the tourists and leads to them having feelings of trust.

\section{2 eWOM had a significant effect on destination trust}

|The respondents in this research were millennial tourists who were visiting the destination for the first time, so their trust in the destination involved eWOM. This study found that eWOM had a significant and positive influence on destination trust. If the eWOM experienced by tourists was positive, they were more likely to trust the destination. Conversely, if the eWOM was negative, tourists were less likely to trust the destination. The results of this study were consistent with the research of Abubakar et al. (2017), Aprilia et al. (2019), and Yerizal and Abror (2019), who found that eWOM influenced destination trust. Trust needs to be further investigated to establish the factors that influence the trust of a destination. eWOM is an important factor that influences trust in a destination, and which is directly related to viral marketing. Viral marketing is the process of individual marketing to each other (Subramani and Rajagopalan, 2003). Therefore, eWOM attracts the attention of tourism marketing because tourists have direct access to many larger sources of information. Tourists are also able to make online purchases instead of relying on a travel agent (Morrison et al., 2001).

\subsection{The destination image had a significant effect on revisit intention}

The respondents in this research were millennial tourists who were visiting the destination for the first time, so they evaluated the destination based on its brand or image. This study found that destination image had a significant and positive influence on the intention to visit again. If the image of the destination was positive, it increased the desire of tourists to visit the destination again. Similarly, if the image of the destination was perceived negatively by tourists, they were less likely to visit again and they would look for alternative destinations instead. These findings were similar to the results of studies by Prayogo and Kusumawardhani (2016), Chen and Tsai (2007), and Chi and Qu (2008). Choi, Tkachenko, and Sil (2011), and Assaker and Hallak (2013) reported that the image of a destination could affect revisit intention. Improvements to the destination image will affect tourist satisfaction and tourist behavior, such as destination choices, evaluations of the destination, and future behavioral intentions (Bigne et al., 2001).

\section{4 eWOM had a significant effect on revisit intention}

The respondents in this research were millennial tourists who were visiting the destination for the first time, so they evaluated their visit based on eWOM. This study found that eWOM had a significant and positive influence on the intention of tourists 
to visit the destination again. If eWOM from online reviews or social media was found to be reliable by the tourists, it encouraged them to visit again. Similarly, if the eWOM proved to be unreliable, then tourists were less likely to visit again, and they would look for alternative destinations.

These results supported the findings of Abu Bakar and Ilkan (2016) and Prayogo and Kusumawardhani (2016). The inherent impact of eWOM on the intention to revisit can be stronger than traditional WOM. Tourists compare the information that they obtained before their visit with their experience of the visit. If the condition of the destination was in accordance with the situation described by the reviews, this encouraged millennial tourists to visit again and reinforced the destination image of the zoo. Tourists who had visited the zoo already knew whether the reviews were accurate, which strengthened the destination trust and the destination brand and increased their intention to revisit. The results of this study indicated that trust in the destination was the key to encouraging tourists to visit again.

\subsection{Destination trust had a significant effect on revisit intention}

The respondents in this research were millennial tourists who were visiting the destination for the first time, so their evaluation was based on their experience of their visit. This study found that destination trust had a significant and positive effect on the intention of tourists to visit again. If the tourists trusted the destination, they had a greater intention to visit again. Similarly, if the trust in the destination was perceived negatively by the tourists, then they had little intention to visit again and would look for alternative destinations. The results of this study were consistent with the research of Abu Bakar and Ilkan (2016). The inherent effect of eWOM on the intention to revisit was stronger than traditional WOM. Tourists sought information from written or spoken reviews by other tourists because tourists consider that information to be more reliable than the information available from travel service providers. Reliable reviews of a destination will result in more trust in the destination. As a result, the destination brand becomes stronger, leading tourists to revisit. The results of this study indicated that trust is the key to encouraging tourists to visit again. In essence, destination trust is the main factor in the decision-making process for tourists deciding whether to revisit a destination. In other words, tourists buy trust or a sense of security from a destination. This finding differs from the study carried out by Mohammed (2016), which proposed that trust was an important antecedent of the attention of tourists to travel to the destination. He demonstrated that trust was the core of the process for selecting destinations and deciding whether to revisit. This is because tourists pay attention to the destination image, so if the image of a destination is positive, then tourists will visit. This finding indicates that the destination image requires trust from the tourists. Before deciding on a destination, tourists search for information and reviews from other tourists on websites and social media such as Facebook and Instagram. They do this to reduce the risks of bad service and disappointment. Tourists rely on the message of eWOM "to reduce the risk from uncertainty in selecting a destination that assures tourists." Tourists look for information through eWOM to ensure that the destination they choose can be relied on.

Before making a purchase, tourists will search for information on which destinations that can be relied on by using the destination image and eWOM. Tourists need certainty. The results of this study found that tourists would revisit if the destination could be relied on. This finding was consistent with the results of Choi, Law, and Heo (2016), who found that trust was a key quality for success in managing the marketing of tourist destinations. Pujiastuti et al. (2017b) also showed that trust is a behavior (affective response) that can influence behavioral intentions (behavioral response). In other words, trust plays an important role in determining the client's intention to spread positive word of mouth. This study has shown that millennial tourists were affected by pull motivation in choosing a destination and in deciding to revisit. The pull factor is the reason a tourist goes to a certain destination. The results of this research have demonstrated the ability of a destination, such as a zoo that attracts millennial tourists. The attitudes of millennial tourists towards a destination can be used as a measure of the ability of the destination management to attract tourists. This study showed that zoos were attractive to millennial tourists and destinations featuring animals were attractive and had a pull factor. For destinations like zoos or animal farms, this finding could help them to build up more tourist visits by becoming more attractive. The pull factor was conveyed successfully by millennial tourists through eWOM and destination image. A positive destination image for a zoo includes hygiene, cleanliness, a variety of interesting amusement rides that are different from other destinations, and a variety of animals. Other pull factors offered by a zoo are the maintenance factors and situational factors (safety, security). This study proposed that trust was a motivating factor for tourists deciding on a destination. Tourists who already have trust in a destination will have a strong willingness or sense towards the destination. Trust is an emotional bond that is not visible but can be very strong between tourists and a destination. An effective evaluation becomes relevant to the destination when it is grounded in a basic premise of environmental psychology: that people experience emotional responses to different places (Mehrabian and Russell, 1974). Trust is an expression of the feelings expressed by tourists towards a place (Gartner, 1993). Trust is a key relationship between tourists and the destination, so managers need to build trust if they want to attract tourists who will revisit. Trust is important because tourists are always going to evaluate destinations based on emotional experiences. Trust is one of the pull motivations that influence tourists when choosing a new destination or revisiting a previous destination.

\section{Conclusion}

This study has found that destination image and eWOM had both direct and indirect (through destination trust) effects on the intention of tourists to revisit. From a theoretical perspective, this research contributes to a greater understanding of two areas. First, this study is one of several works that have attempted to identify the factors that affect revisit intention. Second, revisit 
intention can be formed from the destination image perceived by the tourists before visiting. A positive destination image is strengthened after making a visit that results in satisfaction. Online recommendations (eWOM) may affect tourists in the process of decision-making and post-purchase when they consider revisiting.

\subsection{Practical implications}

Satisfied tourists are more likely to return to a destination and more willing to share their positive travel experiences with their friends and relatives. This is because tourists value recommendations from friends or relatives before deciding to visit a place. Satisfied tourists who have a strong positive impression of a particular destination will tell others so that a positive image of the destination is established.

\subsection{Research limitations and directions for future research}

This study only used three variables - destination image, eWOM, and satisfaction. Therefore, further research on revisit intention with millennial tourists should incorporate other variables into the model.

\section{References}

Abubakar, A. M., \& Ilkan, M. (2013). More adverts or more Ewom's. Journal of Business Financial Affairs, $2(2), 129$.

Abubakar, A. M., \& Ilkan, M. (2016). Impact of online WOM on destination trust and intention to travel: A medical tourism perspective. Journal of Destination Marketing \& Management, 5(3), 192-201.

Ajzen, I. (1991). The theory of planned behavior. Organizational behavior and human decision processes, 50(2), 179-211.

Aprilia, S., Devi, Pujiastuti, Eny Hadi, E.D., Lukmono, Destinasi, P.C. (2019). E-WOM terhadap Kepuasan Wisatawan dan Kepercayaan (Studi Pada Wisatawan yang berkunjung Tebing Breksi Daerah Istimewa Yogyakarta), Jurnal Dialektika, $4(1)$.

Assaker, G., \& Hallak, R. (2013). Moderating effects of tourists' novelty-seeking tendencies on destination image, visitor satisfaction, and short-and long-term revisit intentions. Journal of Travel Research, 52(5), 600-613.

Baloglu, S., \& McCleary, K. W. (1999). A model of destination image formation. Annals of tourism research, 26(4), 868897.

Bennett, S. (2014). Social media business statistics, facts, figures \& trends 2014. Social Times. Available at http://www.adweek.com/socialtimes/social-business-trends-2014/498129 (accessed 6-11-2017).

Bigne, J. E., Sanchez, M. I., \& Sanchez, J. (2001). Tourism image, evaluation variables and after purchase behaviour: interrelationship. Tourism Management, 22(6), 607-616.

Chen, C. F., \& Phou, S. (2013). A closer look at destination: Image, personality, relationship and loyalty. Tourism management, 36, 269-278.

Chen, C.-F., \& Tsai, D. 2007. How destination image and evaluative factors affect behavioral intentions? Tourism Management, 28(4), 1115-1122.

Chi, C.G.-Q., \& Qu, H. (2008). Examining the structural relationships of destination image, tourist satisfaction and destination loyalty: An integrated approach. Tourism Management, 29(4), 624-636.

Choi, M., Law, R., \& Heo, C. Y. (2016). Shopping destinations and trust-tourist attitudes:Scale development and validation. Tourism Management, 54, 490-501.

Choi, G. J., Tkachenko, T., \& Sil, S. (2011). On the destination image of Korea by Russian tourists. Tourism Management, 32(1), 193-194.

Court, B. C., \& Lupton, R. A. (1997) Customer portfolio development: Modeling destination adopters, inactives, and rejecters. Journal of Travel Research, 36(1), 35-43

Cole, S.T., \& Scott, D., (2004). Examining the mediating role of experience quality in a model of tourism experiences. Journal of Travel and Tourism Marketing, 16(1), 79-90.

Compete, Inc. (2007). Consumer Generated Content: Learning from Travel Innovators. Available from https://media.competeinc.com/med/uploads/files/ traveltrends_consumer_generated_travel_content.html. Accessed on Sept. 8, 2008.

Dellarocas, C. (2003). The digitization of word of mouth: promise and challenges of online feedback mechanisms. Management Science, 49(10), 1407-1424.

Destiana, A., Pujiastuti, Sadeli, E.E.D. (2019). Pengaruh destination image and tourist atraction towards tourist satisfaction. Journal of Tourism and Creativity, 3(2)

Echtner, C. M., \& Ritchie, J. B. (1991). The meaning and measurement of destination image. Journal of Tourism studies, 2(2), $2-12$.

Jeong, E., \& Jang, S. S. (2011). Restaurant experiences triggering positive electronic word-of-mouth (eWOM) motivations. International Journal of Hospitality Management, 30(2), 356-366.

Forrester Research (2006). The State Of Retailing Online: The $9^{\text {th }}$ Annual Shop.org Study. Published by Shop.org, June 2006. Available from http:// www.clickz.com/3611181. Accessed on Dec. 16, 2008

Gartner, W. C. (1993). Image formation process. Journal of Travel and Tourism Marketing, 2(2/3), 191-215.

Gretzel, U., \& Yoo, K. H. (2008). Use and impact of online travel reviews. Information and communication technologies in tourism, 35-46. 
Gruen, T. W., Osmonbekov, T., \& Czaplewski, A. J. (2006). eWOM: The impact of customer-to-customer online know-how exchange on customer value and loyalty. Journal of Business research, 59(4), 449-456.

Hennig-Thurau, T., Gwinner, K. P., Walsh, G., \& Gremler, D. D. (2004). Electronic word-of-mouth via consumer-opinion platforms: what motivates consumers to articulate themselves on the internet?. Journal of interactive marketing, 18(1), 38-52.

Hsu, C., \& Cai, L. A. (2009, August). Brand knowledge, trust and loyalty-a conceptual model of destination branding. In International CHRIE conference-refereed track (p. 12).

Lee, C. K., Lee, Y. K., \& Lee, B. (2005). Korea's destination image formed by the 2002 World Cup. Annals of Tourism Research, 32(4), 839-858.

Marinao, E., Chasco, C., \& Torres, E. (2012). Trust in tourist destinations. The role of local inhabitants and institutions. Academia. Revista Latinoamericana de Administración, (51), 27-47.

Mehrabian, A., \& Russell, J. A. (1974). An approach to environmental psychology. Cambridge, MA: MIT Press.

Mohammed Abubakar, A. (2016). Does eWOM influence destination trust and travel intention: a medical tourism perspective. Economic research-Ekonomska istraživanja, 29(1), 598-611.

Moorman, C., Deshpande, R., \& Zaltman, G. (1993). Factors affecting trust in market research relationships. Journal of Marketing, 57(1), 81-101.

Morgan, R. M., \& Hunt, S. D. (1994). The commitment-trust theory of relationship marketing. Journal of marketing, 58(3), 20-38.

Munhurrun, P. R., Seebaluck, V.N., \& Naidoo, P. (2015). Examining the structural relationships of destination image, perceived value, tourist satisfaction and loyalty: case of Mauritius. Procedia - Social and Behavioral Sciences, $175,252-$ 259.

Papathanassis, A., \& Knolle, F. (2011). Exploring the adoption and processing of online holiday reviews: A grounded theory approach. Tourism Management, 32(2), 215-224.

Pendergast, D. (2010). Getting to know the Y generation. Tourism and generation Y, 1, 1-15.

Pizam, A. (1999). The American group tourist as viewed by British, Israeli, Korean, and Dutch tour guides. Journal of Travel Research, 38(2), 119-126.

Prayogo, R. R., \& Kusumawardhani, A. (2017). Examining Relationships of Destination Image, Service Quality, e-WOM, and Revisit Intention to Sabang Island, Indonesia. Asia-Pacific Management and Business Application, 5(2), 89-102.

Prensky, M. R. (2012). From digital natives to digital wisdom: Hopeful essays for 21st century learning. Corwin Press.

Pujiastuti, N., Suharyono, \& dan Kusumawati, (2017a). Study on destination image satisfaction trust and behavioral intention: A study in the tourist village in Sleman, Yogyakarta. International Journal of Administrative Science, 148-159.

Pujiastuti, N., Suharyono, \& dan Kusumawati, (2017b). The antecedents behavioral intention regarding rural tourism destination. Asia Pacific Journal of Tourism Research. 22(11), 1169-1181

Saxena, G. (2003). Relationships, networks and the learning regions: Case evidence from the Peak District National Park. Tourism Management, 26(2), 1-13

Sirdeshmukh, D., Singh, J., \& Sabol, B. (2002). Consumer trust, value and loyalty in relational exchanges. Journal of Marketing, 66(1), 1537.

Sterve, J. (2010). Social media metrics. How to measure and optimize your marketing investment. New Jersey: John Wiley \& Sons.

Subramani, M.R., \& Rajagopalan, B. (2003). Knowledge - sharing and influence in online social networks via viral marketing. Communications of the ACM, 46(12), 300-307.

Tsay-Voger, M., Shanahan, J., \& Signorielli, N. (2018). Social media cultivating perceptions of privacy: A 5-year analysis of privacy attitudes and self - disclosure behaviors among Social Media users. New Media \& Society, 20(1), $141-161$.

Um, S., Chon, K., \& Ro, Y. (2006). Antecedents of revisit intention. Annals of Tourism Research, 33(4), 1141-1158

Vásquez, C. R., Suárez, A. L., \& Bíaz, M. A. M. (2005). Trust as a key factor in successful relationships between consumers and service providers. The Service Industries Journal, 25(1), 83-101.

Vogt, C. A., \& Fesenmaier, D. R. (1995). Tourists and retailers` perceptions of services. Annals of Tourism Research, 22(4), 763-780.

Wilson, A., Murphy, H., \& Cambra, F.J. (2012). Hospitality and travel: The nature and implications of user-generated content. Cornell Hospitality Quarterly, 53(3), 220-228

Xiang, Z., \& Gretzel, U. (2010). Role of social media in online travel, information search. Tourism Management, 31(2), 179188.

Yoon, Y., \& Uysal, M. (2005). An examination of the effects of motivation and satisfaction on destination loyalty: A structural model. Tourism Management, 26(1), 45-56.

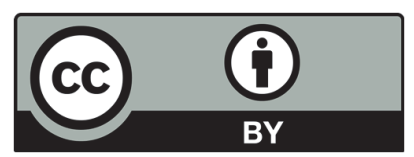

(C) 2020 by the authors; licensee Growing Science, Canada. This is an open access article distributed under the terms and conditions of the Creative Commons Attribution (CC-BY) license (http://creativecommons.org/licenses/by/4.0/). 